\author{
Radosław Kucharczyk \\ University of Warsaw \\ ul. Dobra 55 \\ 00-312 Warszawa
}

\title{
United in Multilingualism. \\ A Few Words about the Didactics of Multilingualism
}

\begin{abstract}
Multilingualism is intrinsically linked with the European Union. Therefore, many European documents contain recommendations concerning its promotion, especially in the context of education. This paper describes the main axes of the European language policy. It also presents a suggested strategic model of developing plurilingual competence, which is one of the principal objectives of contemporary language teaching. The central point of the proposed model is the acquisition by pupils of the ability to make a conscious inter-language transfer, which requires them to create a set of strategies based on the resources of the language repertoire. This implies directing the didactic activities to the development of the ability to learn and emotional management that accompanies it, which requires the student to adopt a reflective attitude.

Keywords: plurilingual competence; transfer; ability to learn; affectivity; reflection; inter-language transfer
\end{abstract}

1. The place of multilingualism in the education policy of the European Union

Multilingualism is an inherent part of the daily life of the European Union, which may be considered both in social and individual 
categories. It is regarded as a value that should be protected and cared for, as it guarantees a coherent functioning of the Community. Thus, it is not surprising that the multilingualism is one of the priorities of the European education policy, and the school is, par excellence, the place where learners are taught tolerance towards multilingualism. In the context of the deliberations contained in this paper, it seems important to quote the Presidency Conclusions announced at the meeting of the European Council in Barcelona, in $2002^{1}$. In the conclusions regarding education policy, the Presidency calls the Member States "to improve the mastery of basic skills, in particular by teaching at least two foreign languages from a very early age." From the perspective of language education, it is a very important decision: learners should not only start learning a foreign language at an early school age (or even in kindergarten), but also learn two compulsory foreign languages during their mandatory school education. Therefore, it should be no surprise that the list of 8 key competences contained in the Recommendation of the European Parliament and of the Council of 18 December 2006 on key competences for lifelong learning starts with such skills as communication in the mother tongue and in foreign languages. The key competences constitute a category called transversal competences, being competences developed during different didactic activities (i.e. various types of assignments and different school subjects). They are defined as a function of knowledge, skills and approaches that allow the learners to adapt to the changes that occur (faster and faster) in their surroundings, and thus allow them to acquire new knowledge and skills after graduation, during formal education. Emphasising the ability to master the mother and foreign tongues, as a skill that will serve the learners in the future, is an important step in promoting multilingualism. When discussing the place occupied by multilingualism in the European Union's education policy, we may not forget about the New Framework Strategy for Multilingualism of 2005, where an extensive chapter is

${ }^{1}$ http://oide.sejm.gov.pl/oide/images/files/dokumenty/konkluzje/barcelona200203.pdf $(18 / 03 / 2017)$ 
devoted to learning and teaching of languages. The authors notice that the knowledge of foreign languages constitutes a desirable skill of the EU citizens, as it enhances their openness to the diversity of cultures and opinions, favourably influences the cognitive skills, and improves the knowledge of a foreign language. The document distinguishes seven areas of language policy, in which multilingualism can be promoted:

1) National strategies: a consistent system of language teaching, making the learners aware of linguistic diversity, learning of minority and regional languages;

2) Better teacher training: considering new trends in glottodidactics that promote multilingual teaching, departing from the standardised teaching of foreign languages for the benefit of communication skills;

3) Early language training: beginning the foreign language learning as soon as possible, appropriate preparation of teachers;

4) Content and language integrated learning: teaching of subjects with the (partial) use of foreign languages;

5) Languages in higher education: promoting multilingualism and mobility among teachers and learners;

6) Developing the academic field of multilingualism: creating scientific units that conduct research on multilingualism;

7) European Indicator of Language Competence: collecting reliable data on the language skills presented by school pupils. A similar view is shown in the Council Resolution of 21 November 2008 on a European strategy for multilingualism, where the authors encourage the Member States to increase awareness of the benefits of language diversity and language learning among members of the public. The Member States should:

- provide a high level of foreign language teaching and a diverse range of languages at schools, in order to implement the concept "native language + two foreign languages"; 
- make efforts to promote the acquisition and regular updating of language skills for all, in formal, non-formal and informal contexts;

- promote rarely taught and used languages during school education;

- encourage the learning of foreign languages using innovative didactic measures and methods based on inter-language relationship;

- promote learner assessment on the basis of uniformed tools (such as CEFR or European Language Portfolio);

- devote particular attention to the further training of language teachers;

- foster and facilitate exchanges among language teachers, with the aim to increase contact with the target language in real-life communication;

- use numerous European programmes in order to give learners and teachers an opportunity to travel and thus to improve their language competence.

2. Plurilingual competence as an objective of contemporary language teaching

The previous section of the article allows us to conclude that multilingualism is a value to be protected and promoted, and that the school is an excellent place to do that. Therefore, it is not surprising that the glottodidactic paradigm has been changed, and is currently not only focused on the promotion of multilingualism among language learners, but also considers their previous language experience, with the aim of more effective acquisition of subsequent foreign languages. The authors of the Common European Framework of Reference for Languages (hereinafter: CEFR) $\left(2003^{2}\right)$ indicate the so-called plurilingual approach as a one that marks the main routes for didactic activities made by the foreign language teacher during classes.

\footnotetext{
${ }^{2}$ English version 2001, Polish version 2003.
} 
Assuming that the contemporary citizens are increasingly mobile, and therefore they more often meet people who speak different languages, the authors of CEFR believe that the participants of exolingual communication activate those components of their language resources that ensure an effective exchange of information. They express their point of view as follows:

For instance, partners may switch from one language or dialect to another, exploiting the ability of each to express themselves in one language and to understand the other. In a different case, someone may attempt to understand the meaning of a text written or said in an "unknown" language using their knowledge of other languages, i.e. by identifying, in an incomprehensible text, words known from the common, international vocabulary. (CEFR, 2003: 16)

Therefore, it seems natural that one of the main objectives of language teaching is the work on improving the plurilingual competence, which is defined in CEFR (2003: 145) as follows:

Plurilingual competence (...) refers to the ability to use each known language for communication purposes (...), if the person shows different degrees of fluency in the communication using several languages (...). It does not mean a hierarchical co-existence of separate competences, but rather the existence of a single, complex competence exploited by the user.

The fragment of CEFR cited above constitutes a sort of (r)evolution in the glottodidactic thought. Previously, the communicative competence in target language "overlapped" with the parallel competence that the learner had in their native language. Presently, the emphasis on improving the plurilingual competence during a foreign language lesson makes us depart from the classical dichotomy of the native and foreign languages for the benefit of a single common communication competence covering all language resources, among which the user activates those resources that will allow them to effectively transfer their communicational intention or to understand the intentions of their interlocutor. In other words, plurilingual competence may be defined as an integrated competence: it is not a simple sum of the language competences composing one's language resources, but a network of connections created between different languages, which the person uses depending on communication purposes. Therefore, we 
may assume that the plurilingual competence is also an adaptive competence, i.e. the ability to creatively and flexibly express the knowledge acquired at school in out-of-school contexts, by activating the learner's own cognitive, motivational and affective resources (Sujecka-Zając, 2016: 30-31). When considering the issue of multilingualism, we must assume that the learner has certain knowledge on language and communication, and is able to use that knowledge while learning subsequent languages, which (though different) have a lot in common. The learner is aware of the strategies used to learn a language and to use it for communication, which allows them to transfer these strategies to the process of learning subsequent languages and to select the strategies that will be most effective when performing a specific task. The learner also knows the objective of learning and already has some experience in managing emotions, which enables them to control the affective area of learning subsequent languages. Moreover, the learner accepts themselves as a multilingual person, i.e. they are aware that they are not always fully competent in the languages they are learning, and that language acquisition is a long and relatively laborious process.

Thus, the main features of plurilingual competence include its incomplete and partial nature (Robert and Rosen, 2010: 57). That partiality may emerge both at the level of knowledge of different languages composing one's linguistic resources (Language $\mathrm{A}$ is mastered better than Language B), and at the level of skills that the learner shows in a given language (e.g. reading skills can be better than writing skills). Therefore, we may assume that the plurilingual competence is partial, which should not be, however, considered as a deficiency of the teaching process but rather as its natural component (Janowska, 2011: 64). Such a point of view seems to be reasonable, as if the learner learns several languages, it is virtually impossible that they master all of them at the same level. We should also emphasise that the plurilingual competence is variable. The components of the learner's language resources are constantly reconfigured, depending on the travel experience, occupation or family history. 
The authors of CEFR have also underlined the benefits that the user obtains from a developed plurilingual competence. These benefits include such elements as (Robert and Rosen, 2010: 58):

- developed language and communication awareness, which allows them for conscious learning of subsequent languages;

- developed sociolinguistic and pragmatic competences;

- faster and more effective learning of subsequent languages;

- elimination of linguistic and cultural bias.

3. Didactics of multilingualism - proposed definition

Given the above deliberations, we could assume the existence of the so-called didactics of multilingualism, which would promote the process of learning and teaching of languages based on the use of learners' language resources as well as their previous experience in learning.

\subsection{Pluralistic approaches}

The main trend that matches the assumptions of the didactics of multilingualism is the so-called pluralistic approaches (fr. approches plurielles), which have been specifically described in A framework for reference for pluralistic approaches (fr. Un Cadre de Référence pour les Approches Plurielles). The pluralistic approaches are defined as follows:

The term pluralistic approaches to languages and cultures refers to the didactic approaches using such techniques of teaching/learning that refer simultaneously to several (=more than one) language and cultural systems. These approaches are different from the ones that we can call "unit approaches", which take into account only one language or culture and discuss them in separation from a broader entirety. Such "unit approaches" were particularly emphasised in the period of traditional and then communicational methods, which do not allow any reference to the native language in the process of learning. (CARAP, 2012: $6^{3}$ )

\footnotetext{
3 „Nous appelons Approches plurielles des langues et des cultures des approches didactiques qui mettent en ouvre des activités d'enseignement-apprentissage qui impliquent à la fois plusieurs (= plus d'une) variétés linguistiques et culturelles. Nous les opposons aux approches que l'on pourrait appeler „singulières” dans lesquelles le
} 
The presented assumptions included in different approaches highlight the integrated nature of linguistic competences shown by language users, which depend on their linguistic resources. In other words, while learning a new (subsequent) language, the learner relies on the knowledge and skills that they acquired in other (native and foreign) languages, and compares the new with the known, trying to find some equivalence in linguistic ambiguity. Such a search for similarities may exist in different areas: in pure linguistics (looking for similarities within language sub-systems), communication (looking for similarities in discursive and communicational schemes), and in solving complex tasks (looking for analogies regarding the previously verified methods and techniques). The authors also indicate the need to work on the so-called global competences (fr. les compétences globales), which condition the development of plurilingual competence. They distinguish seven main and six secondary competences, all shown in the following table:

Table 1. Global competences supporting the development of inter-language and intercultural competences (source: CARAP, 2012: 20)

\begin{tabular}{|c|c|c|c|}
\hline & Main global competence & & Secondary global competence \\
\hline \multirow[t]{4}{*}{$\mathrm{C} 1$} & \multirow{4}{*}{$\begin{array}{l}\text { Competence in managing } \\
\text { linguistic and cultural } \\
\text { communication in a context of } \\
\text { "otherness" }\end{array}$} & $\mathrm{C} 1.1$ & $\begin{array}{l}\text { Competence in resolving conflict, } \\
\text { overcoming obstacles, clarifying } \\
\text { misunderstandings }\end{array}$ \\
\hline & & $\mathrm{C} 1.2$ & Competence in negotiation \\
\hline & & $\mathrm{C} 1.3$ & Competence in mediation \\
\hline & & $\mathrm{C} 1.4$ & Competence of adaptability \\
\hline $\mathrm{C} 2$ & $\begin{array}{l}\text { Competence in the construction } \\
\text { and broadening of a plural } \\
\text { linguistic and cultural }\end{array}$ & $\mathrm{C} 2.1$ & $\begin{array}{l}\text { Competence in profiting from } \\
\text { one's own inter-cultural / inter- } \\
\text { language experiences }\end{array}$ \\
\hline
\end{tabular}

seul objet d'attention pris en compte dans la démarche didactique est une langue ou une culture particulière, prise isolément. Ces approches singulières ont été tout particulièrement valorisées lorsque les méthodes structurales puis communicatives se sont développées et que toute traduction, tout recours à la langue première étaient bannis de l'enseignement." 


\begin{tabular}{|l|l|l|l|}
\hline & repertoire & C2.2 & $\begin{array}{l}\text { Competence in applying systematic } \\
\text { and controlled learning approaches } \\
\text { in a context of otherness }\end{array}$ \\
\hline C3 & Competence of decentring & \multicolumn{2}{|l}{} \\
\hline C4 & $\begin{array}{l}\text { Competence in making sense } \\
\text { of unfamiliar linguistic and/or } \\
\text { cultural features }\end{array}$ & \\
\hline C5 & $\begin{array}{l}\text { Competence of distancing } \\
\text { C6 }\end{array}$ & $\begin{array}{l}\text { Competence in critical analysis } \\
\text { of the (communicative and/or } \\
\text { learning) activities one is } \\
\text { involved in }\end{array}$ \\
\hline C7 & $\begin{array}{l}\text { Competence for recognising } \\
\text { the "Other", and otherness }\end{array}$ \\
\hline
\end{tabular}

The authors systematize the hitherto teaching practices, which are based on the use of learners' language resources, and distinguish 4 approaches: intercultural approach (fr. approche interculturelle), awakening to language (fr. éveil aux langues), intercomprenhension of related languages (fr. intercompréhension entre les langue sparentes) and integrated didactics (fr. didactique intégrée). Three of these approaches directly refer to the development of plurilingual competence and therefore will be summarised further in this paper.

Awakening to language is to accustom the learners to linguistic diversity, which surrounds them and which they can meet in the future, and to give them a foundation for future learning of languages. The learners perform numerous exercises, which involve a comparison of languages that are not taught at school, in order to find some similarities and to become accustomed to strange sounds.

The objective of the intercomprehension of related languages is to develop receptive skills (mostly regarding written texts) in languages which do not belong to the learners' language family, yet the authors do not exclude the work on improving the skill of understanding spoken texts at a later stage.

When it comes to integrated didactics, it is defined by the authors of A framework for reference for pluralistic approaches as an approach that is to help learners to become aware of the relations 
between the languages taught at school. Didactic activities tend towards the improvement of all linguistic skills and language subsystems.

3.2. The didactics of multilingualism during second foreign language lessons

As stated above, the pluralistic approaches allow us to improve plurilingual competence and suggest didactic activities based on the use of learner's language resources, which is in accordance with the assumptions of the didactics of multilingualism. However, this leads to a question whether it is possible to implement the assumptions of the pluralistic approaches in the process of language teaching at school (i.e. in formal education). The awakening to language is a very interesting didactic approach, but at which subject should we implement it? A similar question concerns intercomprehension, which may be very useful in continuing education, when the learners (working adults) need an incomplete language competence (e.g. reading of professional texts in a foreign language). However, we must remember that the goal of teaching and learning at school is that the learners acquire the skill of oral and written communication in the target language. The integrated didactics might probably be applied in school teaching, but are there many teachers who (apart from their mother tongue and the foreign language that they teach) are sufficiently fluent in a third language to make conscious and "professional" inter-language comparisons? Therefore, we could try to create a glottodidactic model based on the learner's language resources, which could be used in formal education, at a foreign language class. A central element of such a model would be the learners' acquisition of the skill of multi-language transfer based on their language resources. This would imply the need that the learners develop a highly individualised range of strategies based on their language potential. These would in turn entail the work on their learning skill (learning to learn), the appropriate direction of their thought on the functioning of language, communication and language learning, and the consideration of the affective area in the process of learning and teaching. 


\subsubsection{Transfer}

Transfer is nothing more than an action based on the learner's intellectual activeness, which allows them not only to extend their competence in different (often broader) fields of activity, but also gives the opportunity to acquire higher-level competences, provided that first the learner masters the basic competences that for a sort of scaffolding (Arenilla et al., 2007: 315-316). Thus, it seems reasonable that the role of the teacher is to provide the learners with tools that will make such a transfer easier. The following table shows the stages which can help the learners to use what they already know in order to acquire new knowledge and skills (Samson, 2011).

Table 2. Stages of transfer (source: Samson, 2011, online)

\begin{tabular}{|l|l|l|l|}
\hline No. & \multicolumn{1}{|c|}{ Stage } & \multicolumn{1}{c|}{ Purpose } & \multicolumn{1}{c|}{ Teacher's task } \\
\hline 1. & $\begin{array}{l}\text { Becoming aware of } \\
\text { the knowledge and } \\
\text { skills acquired } \\
\text { before }\end{array}$ & $\begin{array}{l}\text { To create a reference } \\
\text { framework in order to } \\
\text { decode new information }\end{array}$ & $\begin{array}{l}\text { To give learners a range of } \\
\text { questions that will allow } \\
\text { them to reactivate their } \\
\text { existing knowledge and } \\
\text { skills necessary to solve a } \\
\text { new cognitive problem }\end{array}$ \\
\hline 2. & $\begin{array}{l}\text { Learning } \\
\text { categorisation }\end{array}$ & $\begin{array}{l}\text { To develop a range of } \\
\text { concepts in order to } \\
\text { refer to them during the } \\
\text { transfer }\end{array}$ & $\begin{array}{l}\text { To present the learners } \\
\text { with model techniques } \\
\text { used to create conceptual } \\
\text { networks (e.g. a matrix of } \\
\text { thoughts) }\end{array}$ \\
\hline 3. & Reason of learning & $\begin{array}{l}\text { To motivate the learners } \\
\text { for learning }\end{array}$ & $\begin{array}{l}\text { To present the } \\
\text { situations/issues that the } \\
\text { learners already know }\end{array}$ \\
\hline 4. & $\begin{array}{l}\text { Transfer of } \\
\text { knowledge and skills }\end{array}$ & To facilitate learning & $\begin{array}{l}\text { To propose such didactic } \\
\text { situations that allow the } \\
\text { learners to make the } \\
\text { transfer (explicit transfer } \\
\rightarrow \text { implicit transfer) }\end{array}$ \\
\hline
\end{tabular}

Transfer is not a new concept in language learning and teaching. However, inter-language transfer is often considered as a negative phenomenon which should be avoided, as otherwise it leads to adverse linguistic interference. Meanwhile, conscious inter-language transfer 
may considerably facilitate the learning of new languages, which the learners will perceive as "less foreign", provided that the teacher helps them find some analogies between the languages that the learners already know and the ones that they are studying. To summarise the transfer stages presented in the table above, we can say that the teacher should explain, during a language class, that both the language and the communication create a coherent system which is subject to specific rules that are similar in different languages. In other words, when learning a language, the learners can use their previous experience, including the one acquired in their mother tongue, which will allow them to develop a highly individualised (i.e. depended on the language experience of each individual learner) reference framework, to which they will refer during learning. The same applies to learning categorisation. Learners who start learning the next language already have a certain system of concepts that they can use. In addition, the reason of learning should raise no doubts of the learners: they know that the language is used to communicate with people representing other cultures and allows us to take a different (broader) view on different phenomena (not only related to language). What is important, the inter-language transfer may also exist on a strictly linguistic (language sub-systems) or communicational (discursive schemes) plane, as well as when trying to solve a task which requires the learners to activate not only their language-related communication competence but also the general competences.

\subsubsection{Strategies}

A prerequisite for effective and positive inter-language transfer is that the learners develop a range of strategies based on their language resources. Strategy is not a new concept in the glottodidactics. Strategies are usually defined as activities that allow the learners to reach their objectives using relatively low effort. Despite the existence of numerous classifications of language learning, there is no classification that would take into account the learners' language resources. It would be tempting to create a set of strategies that would be based on the knowledge and skills that pupils have in other 
languages (in mother tongue and foreign languages) and which would refer to the three areas determining the learning process: cognitive, metacognitive and social-affective. Strategies based on language repertoire resources would be closely linked to the other learning strategies that a student normally activates while learning a language, but would nevertheless combine them with a common denominator as is to make informed interlingual comparisons. Cognitive strategies would affect the language learning subsystems (primarily vocabulary and grammar) and the development of language skills. Metacognitive strategies would involve the student's activities in planning, controlling and evaluating the learning of another foreign language and solving language tasks. On the other hand, social-affective strategies would be related to emotions that accompany language learning and interaction with other people. We could therefore try to propose such a classification. The following table shows a collection of strategies based on the learner's language resources:

Table 3. Plurilingual Strategies

\begin{tabular}{|c|}
\hline Plurilingual Cognitive Strategies \\
\hline $\begin{array}{l}\text { Learning the target language (vocabulary, grammar, phonetics, etc.), I make } \\
\text { comparisons with other languages that I know. }\end{array}$ \\
\hline In languages I know I see words borrowed from other languages. \\
\hline $\begin{array}{l}\text { In languages I know I see the 'international' words (so-called internationalisms or } \\
\text { transparent words). }\end{array}$ \\
\hline $\begin{array}{l}\text { When learning the grammar of the target language, I try to reach its regularity by } \\
\text { referring to the grammar of the languages I know. }\end{array}$ \\
\hline $\begin{array}{l}\text { In learning the target language, I use skills - related to reading, listening, writing } \\
\text { and speaking - acquired in other languages. }\end{array}$ \\
\hline $\begin{array}{l}\text { I remember that different types of texts in different languages share many common } \\
\text { points. }\end{array}$ \\
\hline Plurilingual Metacognitive Strategies \\
\hline I try to determine the purpose of learning another language \\
\hline $\begin{array}{l}\text { Referring to my previous experience in language learning, I try to identify my } \\
\text { weaknesses and strengths. }\end{array}$ \\
\hline $\begin{array}{l}\text { Before tackling a task in a foreign language, I wonder how I solved similar tasks in } \\
\text { other languages I know. }\end{array}$ \\
\hline I try to monitor the extent to which my language skills are useful to me in learning \\
\hline
\end{tabular}


another language.

Plurilingual Social and Affective Strategies

I know that learning a language is a long and demanding process, so I will not be offended by learning another language.

Communicating in the next language I learn, I ask my interlocutor for support and - if possible - the use of transparent words/expressions.

\subsubsection{Reflection}

The strategies, and thus the inter-language transfer, are determined by the degree of the learner's reflectiveness. Reflectiveness is identified with the change in the learners' awareness resulting from their critical approach taken when solving a problem (Jedynak, 2014: 98). The change of awareness includes 3 levels:

- Task, taken literally: understanding of the language system (communication skills, meta-linguistic knowledge).

- Personality: the learner's individual factors, such as cultural identity, self-esteem, improvement of autonomy, etc.

- Learning context: management of the learning process.

The assumptions of the didactics of multilingualism are largely based on the learners' reflectiveness, which is even indicated in the definition of the plurilingual approach presented in the first part of this article. Let us think: can we imagine the skill of switching between languages or trying to understand the meaning of a text in an "unknown" language without any reflection on the possibilities provided by our language resources? The elements of reflective thinking can also be noticed in the definition of plurilingual competence, which assumes interaction between the languages that the user knows - the improvement of plurilingual competence is impossible without a reflection on when and in which circumstances those languages can be helpful to one another. Therefore, we should encourage the learners (particularly at an early stage of learning) to such a reflection by answering the following questions:

- Why do I learn a foreign language? What will I need the foreign language for? 
- Consequently, what exactly should I learn?

- How can I motivate myself to learn? Do I have any proven methods that help me positively affect the emotions that appear during learning?

- What knowledge, skills and experience do I have in language learning? Will they be useful in learning another language?

- To what extent does the language that I am learning resemble the languages I already know?

\subsubsection{Learning to learn}

Learning to learn is a function of reflection, which affects the process of developing a range of learning strategies, which in turn directly influence the skill of inter-language transfer. That skill is also mentioned among the key competences referred to at the beginning of this paper. The definition proposed by the authors ${ }^{4}$ highlights such elements as the predisposition to manage our own learning process, the ability to determine our own strengths and weaknesses in acquiring knowledge and skills, and the ability to use previous experience when acquiring new knowledge and skills. The latter component seems to be particularly important in developing the plurilingual competence - it should help the learners in better and more effective learning of new languages. It should be emphasised that the learning to learn, which is based on the assumptions of the didactics of multilingualism, can be analysed in micro- and macro-

\footnotetext{
4 “'Learning to learn' is the ability to pursue and persist in learning, to organise one's own learning, including through effective management of time and information, both individually and in groups. This competence includes awareness of one's learning process and needs, identifying available opportunities, and the ability to overcome obstacles in order to learn successfully ${ }^{4}$. This competence means gaining, processing and assimilating new knowledge and skills as well as seeking and making use of guidance. Learning to learn engages learners to build on prior learning and life experiences in order to use and apply knowledge and skills in a variety of contexts: at home, at work, in education and training. The key factors in developing this competence are motivation and belief in our own capabilities."

http://eur-lex.europa.eu/legal-

content/EN/TXT/?qid=1509089120428\&uri=CELEX:32006H0962 (05/01/2017).
} 
scales. Micro-scale should be understood as the process of solving individual linguistic problems, such as vocabulary learning, exploring a foreign language grammar, training our listening, reading, writing and speaking skills; in other words, it is our work on the components of a broadly understood language competence. The macro-scale of learning to learn in the context of multilingualism refers to the entire process of learning the target language and consists both of strictly linguistic and non-linguistic components. We may assume that the micro-scale of multilingual learning to learn mainly covers the cognitive strategies, though it does not exclude the strategies related to the affective and meta-cognitive aspects of learning. Meanwhile, the micro-scale is mostly connected with the said affective and metacognitive strategies, and less with the strictly cognitive ones.

\subsubsection{Affectivity}

The affective aspect of language learning also influences the ability to make inter-language transfers, and thus determines the development of learning strategies and affects the degree of learners' reflection and their learning to learn. The affective aspect is intrinsically linked with the broadly understood context in which the language learning and teaching processes are conducted, as it determines the learners' approaches towards the language, and consequently affects their motivation. We can mention the following factors which affect the learners' approach towards the language learned:

- availability of language learning (languages offered at school, contact with native speakers);

- the learner's experience in learning that particular language and related self-assessment of their own capabilities;

- the influence of the learner's immediate environment;

- the learner's social representations concerning the target language;

- the usefulness of the language in (professional and social) future life. 
The teacher's role is to manage the teaching process in such a way that the learner is optimally motivated to learn the target language. Therefore, the best way would be to provide such learning conditions that would support the glottodidactic process or to ensure an intensive exposure to the target language (trips to the target-language countries, foreign exchange programmes, educational projects, etc.). It is equally important to show the learners how useful it is to know the language, and to present the analogies with other languages that the learners know, which should favourably affect the motivation and make the learning process easier.

\section{Conclusion}

To summarise the above deliberations, we should realise the assumptions of plurilingual competence by building a glottodidactic model that could be implemented into the school systems. The model would include the work on developing the strategies based on the learner's language resources, which (supported by a properly profiled reflection) would strengthen the learning to learn which results from previously acquired experience in learning foreign languages, support the learner's motivation, and lead to a successful inter-language transfer. The components of such a model (including their hierarchical nature) are presented in the following diagram:

\section{TRANSFER}

\section{strategies}

\section{learning to learn}

Figure 1. The strategic model of developing plurilingual competence 
We should emphasise that the model is highly individual, as its components depend on the starting potential of the learners and are subject to a continuous reconfiguration depending on the knowledge and skills that the learners acquire.

\section{References}

Arenilla, L. et al. 2007. Dictionnaire de pédagogie et de l'éducation. Paris: Bordas.

Candelier, M. et al. 2012. Le CARAP. Un Cadre de Référence pour les Approches Plurielles des Langues et des Cultures. Compétences et ressources. Graz: Centre européen pour les langues vivantes/Conseil de l'Europe.

Europejski system opisu kształcenia językowego. 2003. Warszawa: Centralny Ośrodek Doskonalenia Nauczycieli.

Janowska, I. 2011. Podejście zadaniowe do nauczania i uczenia się języków obcych. Na przykładzie języka polskiego jako obcego. Kraków: Universitas.

Jedynak, M. 2014. Inicjatywy Rady Europy i Komisji Europejskiej na rzecz wspierania refleksyjności nad procesem uczenia się i nauczania języka obcego. Neofilolog, 43(1), 95-110.

Lüdi, G. 2016. Du plurilinguisme comme tare au plurilinguisme comme atout. L'héritage de l'idéologie monolingue. In: G. Komur-Thilloy, U. PaprockaPiotrowska (eds.), L'éducation pluriingue. Contextes, représentations, pratiques. Paris: Orizons, 31-53.

Robert, J.-P., Rosen, É. 2010. Dictionnaire pratique du CECR. Paris: Éditions Ophrys.

Samson, G. 2011. Le transfert a-t-il un avenir dans l'apprentissage et l'enseignement ?». Cahiers pédagogiques.com 〈http://www.cahiers-pedagogiques.com/Letransfert-a-t-il-un-avenir-dans-1-apprentissage-et-1-enseignement> (access 27/04/2016).

Sujecka-Zając, J. 2016. Kompetentny uczeń na lekcji języka obcego. Wyzwania dla glottodydaktyki mediacyjnej. Lublin: Werset/Instytut Romanistyki.

Wilczyńska, W. 2008. Motywy wyboru języka obcego w szkole a unijny postulat rozwijania wielojęzyczności. In: A. Michońska-Stadnik, Z. Wąsik (eds.), Nowe spojrzenie na motywacje $w$ dydaktyce języków obcych. Tom 1. Wrocław: Wydawnictwo Wyższej Szkoły Filologicznej we Wrocławiu, 159-170. 